\title{
THE NEED FOR A NATIONAL MARITIME POLICY
}

This paper was drawn up for and in consultation with VAdm G Syndercombe, SD, SOE, SM. retired Chief of the South African Navy. VAdm Syndercombe used this paper to address the National Maritime Conference, which took place in Cape Town on 11 and 12 May, 1989. VAdm Syndercombe has since then been awarded the Star of South Africa Silver (SSAS). The paper relied on inputs from three Naval Officers, who all at one time were appointed to look after the post of Director Naval Strategy. These officers were:

(a) Capt (SAN) Peter Fougstedt (now Commodore), Chief of Staff, Naval Command East

(b) The late Capt (SAN) C.J. Furness, who passed away on 12 November, 1988. (BMil (Bsc))

(c) Capt (SAN) R.H. Harm, presently Director Naval War Plans. (BMil) (Bsc), BA Hons (Strategic Studies). ${ }^{\star}$

\section{Introduction}

1. This paper is intended to explore the stated need for South Africa to have a national maritime policy. Such a policy must be aimed at a national orchestrated effort to exploit our maritime interests in such a way that we may obtain the optimum results with the limited resources available in order to make this country a maritime power. The scope of this paper is:

- A short introduction.

- Defining National Maritime Policy (NMP).

- The relationship between Maritime Strategy and Maritime Policy.

- Defining National and Maritime Interests and the interaction between them.

- Discussion of our marine interests.

- Discussion of the sources/elements available to further our Maritime Interests.

- Discussion of the elements of a National Maritime Policy.

- Summary.

\section{What is a National Maritime Policy?}

2. If it is accepted that a national policy is a broad statement of guidelines in pursuit of national objectives, a national maritime policy may be defined as: "the policy formulated to achieve the co-ordinated rationalised use of the total maritime assets of the state to the maximum benefit of national interests." In other words this policy should embrace all activities in which the sea or maritime environment is used. "Although the need for this (a maritime policy) is recognised, the RSA does not have a maritime policy." It will, however, become clear that such a policy is required in order to utilise scarce maritime resources. The maximum utilisation of these resources could change this country into a maritime power, where maritime power is defined as "the ability or means of the state to use the sea to further its national interests."

\section{The relationship between Maritime strategy and Maritime Policy}

3. Rather than being the outcome of the overall national maritime policy, South Africa's maritime strategy constitutes a subcomponent of the SADF's general military strategy. The right of the existence of the SADF's maritime forces is based on the realization of objectives of an exclusively military nature. The primary objectives are two-fold, namely in the first instance the defence of the RSA and SWA/Namibia by the employment of all maritime means. Secondly, the objectives are aimed at the protection of the RSA's and SWA/Namibia's maritime assets, this being the SA Navy's contribution to the defence of the sea lines of communications (SLOC) and maritime infrastructure. The responsibility for SWA/Namibia may well disappear on independence.

4. The question may well be asked whether we should have identified a National Maritime Policy for the RSA before formulating a Maritime Strategy.

\section{Defining National Interests and National Objectives}

5. In order to address the correct elements when deciding upon a national maritime policy, it needs to be ensured that these elements have been identified out of the national interests of the State. National interests are defined by J.M. Collins as follows: "National interests are highly generalised concepts or elements that constitute a 
state's compelling needs, including self preservation, independence, national integrity, military security and well-being."

6. The pursuance of national interests is guided by national objectives, which were defined as: "The fundamental aims, goals or purposes of a nation towards which policies are directed and energies are applied."

7. The national maritime interests may be expanded from the national interests, which can be inferred from the Preamble to the Constitution, eg: "To safeguard the integrity and freedom of our country .... to further the contentment and the spiritual and material welfare of all ...". Accordingly the following model can be drawn up:

$\begin{array}{ll}\text { NATIONAL } & \text { NATIONAL MARITIME } \\ \text { INTERESTS } & \text { INTERESTS } \\ \text { (Fundamental } & \text { (need to use the sea to meet } \\ \text { needs) } & \text { fundamental needs) } \\ \text { SECURITY } & \text { MARITIME DEFENCE } \\ \text { ECONOMIC WELL- } & \text { SEABORNE TRADE } \\ \text { BEING } & \text { EXPLOITATION OF MARINE } \\ & \text { RESOURCES }\end{array}$

\section{Discussion of our Maritime Interests}

8. In the discussion of our maritime interests maritime defence will be ignored as one of the aspects of national maritime interests, as the requirement of this cannot be argued. Time will rather be spent discussing seaborne trade and the exploitation of marine resources. This discussion will be kept short.

\section{Seaborne Trade}

9. More than $60 \%$ of the RSA's Gross Domestic Product (GDP) is made up in foreign trade. Our main trading partners are the United Kingdom, the Federal Republic of Germany, the United States and in latter years especially Japan, which can now be regarded as our main trading partner.

10. It must be noted that this country's mining industry is export orientated, due to the fact that $85 \%$ of the income from minerals is earned in foreign countries. As regards the nature of the transportation medium, minerals (with the exception of platinum, diamonds and gold which are transported by air) are carried by ship in bulk as well as in processed form. Consequently, shipping and harbour facilities are of necessity key components of the transport infrastructure.

11. Because of the RSA's expected population growth (1986 - 27 million and the year $2000-47$ million or higher) and the political position that the RSA finds itself in, economic growth is vital to the economic well-being and also to the security of the country. In order to sustain economic growth, the RSA will require increasing imports, particularly of capital goods. Accordingly, exports will also have to increase to enable the RSA to purchase the required imports, and to therefore have a positive balance of payments.

12. It can be concluded that seaborn trade is, and will continue to be, a vital element of the RSA's national maritime interests.

\section{Exploitation of marine resources}

13. Marine resources can be grouped in two main categories, as follows:

(a) Renewable. Renewable resources are:

(i) Aquatic bird guano, eggs, etc.

(ii) Seaweeds.

(iii) Fish, crustaceans, molluscs, etc.

(iv) Marine mammals.

(v) Tourism and Leisure.

(b) Non-renewable. Non-renewable resources are minerals, oil and gas.

14. The RSA has a large fisheries zone out to $320 \mathrm{~km}$ from its coast, which incorporates the productive fishing areas of the West Coast. The heartland of the fishing ground off the West Coast covers approximately 400000 square miles between the mouth of the Kunene River and Cape Point, with Saldanha and Walvis Bay constituting focal points of this industry.

15. The fishing industry forms an important branch of the econumy of the country, providing about 10000 job opportunities, bringing in a total catch value of approximately R480 million per annum. The RSA ranks between 20th and 24 th on the international list of fishing countries.

16. At present the control of all sea fishing is vested in the Government and has been administered by the Department of Environmental Affairs since 1 August 1982. Some functions have been delegated to Provincial Administrations, such as certain coastal activities in Natal where jurisdiction is retained by the Natal Parks Board. 
The Chief Directorate of Marine Development administers various Acts pertaining to the fishing industry and reports to the Minister on policy and legislation. The Minister is also advised by a statutory council on matters relating to various sections of the fishing industry, such as resources exploitation levels of the sea. The Government follows a strict conservation policy for sea fisheries (quotas), pleasure fishing, sea-diving and shell fishing, which is enforced by inspectors.

17. It is fitting to deal with marine ecology here. Pollution of our seas proves to be a serious threat to the marine life along our coast. Many industries and town managements unfortunately still tend to regard the sea as a free sewage system and passing shipping is just as guilty. The necessity to counter pollution (especially oil) must be acknowledged and supported.

18. Tourism is one of the largest industries in the RSA. Beaches and sea holiday resorts feature amongst the main attractions and this resource needs to be exploited to the full benefit of the RSA's economy. Similarly, such beach facilities and offshore areas provide scope for sport and recreation, so vital to a nation's health and wellbeing.

19. As far as the non-renewable marine resources are concerned, diamonds are recovered from the sea-bed off our West coast and gas of our Southern coast. It can be assumed that sea-bed resources will become increasingly more important in the future, especially as the resources on land are gradually being depleted and technology advances and provides man with economical means of exploiting deep sea minerals.

20. An interesting aspect regarding off-shore mining rigs in the North Sea has been the formulation of national policy with respect to the improvement of the legal status of particular groups of employees working on extraction platforms on the Dutch section of the continental shelf. The RSA will also be experiencing an inflow of foreigners to the Mossel Bay project soon. Another area broached by the Dutch was the planning of the development of the coastline littoral to the oil/gas fields as this section of the coast must meet the needs of the gas/oil industry.

\section{The sources and elements available}

21. Now that clarity has been obtained on what our maritime interests are, the sources and elements available in order to further our maritime interests can be discussed. Geoffrey Till described the sources and elements of "sea power" as follows:

Sources

A maritime community Resources

Style of government Geography

22. If the fishing fleets and maritime infrastructure are added to this list, all the components of maritime power are listed. For the purpose of this paper the maritime forces will once again be ignored.

23. Maritime Community. This could be described as that group of the population that make their living from the sea. This description would include all seafarers and those employed in support of maritime activities. However, the national will and the extent to which the population is sea-orientated has to be included. The South African people generally are not seaorientated and the country does not produce sufficient seafarers. Very few young men from our affluent white society embark on a sea-going career, and the sea-going services are drawing more men from the coloured and black groups of the community. A general indifference towards the use of the sea constitutes a weakness in the RSA's maritime component of the power base.

24. National Resources. With the exception of water, the country is blessed with an abundance of natural resources. Together with labour, capital, entrepreneurship and technological expertise these elements determine the economic power of the RSA. The maritime power is, of course, closely linked to a country's economic power. However, there are a number of factors which place a constraint on the country's economic development. These elements include a shortage of skilled manpower, socio-political problems and a lack of sufficient entrepreneurship and technological expertise. In addition the need to import heavy capital and electronic equipment is a limiting factor for economic growth. Because of the RSA's dependence on foreign trade, the country's economy is influenced by and sensitive to changes in the world economy. Despite these constraints on the 
economy, the potential for economic growth is good and the RSA's natural resources on the whole provides a strong base for the development of maritime power. A parting remark with respect to these national-cum-natural resources - they need to be protected, and policy regarding ecology must be orchestrated to ensure our beaches for sport, recreational and tourism purposes.

25. Style of Government. According to Maham: "... particular forms of government with their accompanying institutions, and the character of rulers at one time or another, have exercised a very marked influence upon the development of sea power." The validity of this observation can be illustrated by the manner in which the Soviet Union, as a totalitarian state, has developed its maritime power, while the democratic governments of the United States and Britain have allowed their maritime power to decline. The RSA's government is committed to the free enterprise system, and the style of government has allowed the un-coordinated development of the various elements of the country's maritime power. Development was generally based on commercial considerations and not necessarily in consideration of the national interests. The Government control that does exist over the country's maritime activities, is fragmented amongst various Government departments and agencies. It can be deduced that the RSA's style of government is not conducive to the development of maritime power. The fact that no national maritime policy exists would appear to confirm this deduction.

26. The RSA's geographical position allows easy access to the oceans of the world, and the RSA's dominant position on one of the world's major trade routes need not be expounded upon. Perhaps a few statistics regarding this route in relation to oil might be of interest. The Middle East is the oil producing area which exercises the most direct influence on the strategic importance of the RSA's contiguous oceans. At present, according to estimates, 60 million tons of oil are transported westward annually by sea, i.e from the Middle East. Taking this dependence into account, as well as the future increase in consumption and the fact that more than $50 \%$ of the world's known reserves are to be found in the Middle East, the importance of this area to the West becomes evident. The fact is that these oil imports to the West are transported mainly by ship (very large crude oil car- riers or VLCC's). By using LCCC's over 200000 dwt (deadweight registered tonnage), the Cape sea route is, in economic terms, a much more viable proposition than the Suez Canal. The RSA has several good harbours to back up the services along this route.

27. Maritime Infrastructure. A maritime infrastructure is an essential element of a country's maritime power, as it supports all the maritime activities of the country. The following are the main components of the maritime infrastructure:

(a) Harbours and associated harbour services. The RSA has well-developed harbours with good facilities and services. The harbours are administered by the SA Transport Services, and have a world-wide reputation for reliability and efficiency. The harbours of Richards Bay and Saldanha handle bulk products like coal and iron ore, while Durban is the most important harbour for handling general cargo. Durban and Cape Town also provide the main ship repair and docking facilities in the RSA.

(b) Aids to Navigation. The SA Transport Services are responsible for providing and maintaining navigational aids on the South African coast, which is well marked with lighthouses. The SA Navy provides a hydrographic service which produces navigational charts and publications regarding South African waters.

(c) Cargo Distribution Systems. The RSA's ports are served by excellent road and rail networks, and pipelines for crude oil and petroleum products run inland from Durban. The ports of Durban, Port Elizabeth and Cape Town have modern container terminals and the container handling services in the RSA is one of the best in the world. Inland container terminals are to be found at Johannesburg, Durban and Bellville.

(d) Research Services. Maritime research is carried out by several government departments and institutions:

(i) The Weather Bureau. The Weather Bureau functions as a division of the Department of Transport. Weather stations are maintained on Gough and Marion Islands and at the Sanae base in the Antarctic. The Department of Environmental Affairs operates a supply vessel, the SA AGULHAS, to support these stations.

(ii) The Marine Development Division. The Marine Development Division of the De- 
partment of Environmental Affairs carries out biological, chemical and physical research on sea fisheries. The Institute operates several small research vessels and recently commissioned a large modern research ship (Africana II).

(iii) The Fishing Industries Research Institute (Department of Oceanography). This Institute is affiliated to the University of Cape Town and investigates problems in the field of fisheries technology. The Universities of Stellenbosch and Natal are also involved with aspects of marine research.

(iv) The Council for Scientific and Industrial Research (CSIR). The CSIR administers the National Research Institute for Oceanography and Systems Technology, both of which are involved in maritime research. The privatisation of the CSIR may cause problems in this field in the future.

(v) Sea Rescue Services. The Department of Transport is responsible for the RSA's sea rescue services which are controlled by a co-ordinating body known as the SA Search and Rescue Organisation (SASAR). This organisation does not operate any vessels or aircraft of its won, but may call on the SA Defence Force, SA Transport Services, shipping and airlines and the National Sea Rescue Institute for assistance in rescue operations. The SA Navy is associated with the international Automated Merchant Vessel Search and Rescue Organisation (AMVER) and has already gained standing overseas.

(vi) National Marine Advisory Council. The National marine Advisory Council was created in terms of the Merchant Shipping Act (Act 57 of 1951) to advise the Minister of Transport relating to matters

- Arising out of the Act.

- Connected with merchant shipping in the Republic.

- If referred to it by the Minister, merchant

- shipping in general (other countries).

Council membership shall not be more than 12, eight of whom represent bodies or associations recognised as representative of merchant shipping interest. This body has largely ceased to function.
28. Conclusion. The RSA's maritime infrastructure is generally well-developed and constitutes a strong element of the country's maritime power.

29. The fishing fleet. According to Admiral Gorshkov a country's fishing fleet is one of the main components of the maritime power of the state. We have already discussed fishing as a major activity under the exploitation of the RSA's marine resources. The fishing fleet is a relatively well developed element of the RSA's maritime power.

30. Merchant shipping. Merchant shipping is an essential element of a country's maritime power, as it provides the means to use the sea for foreign trade. The size and effectiveness of a country's merchant navy is an important factor in the assessment of it's maritime power. South African shipping companies, of which SAFMARINE and Unicorn Lines are the largest, represent a strong element of the country's maritime power. This element is, however, weakened by the number of SA owned vessels that are registered under foreign flags. Although this allows greater freedom of entry into certain foreign ports, such vessels can be vulnerable to interference and pressures from foreign governments. The mere possession of an ID document, such as a passport or "seaman's book" indicating SA citizenship, can lead to crew members being refused access to medical and dental treatment or other discriminatory practices.

\section{Elements of a National Maritime Policy}

31. Having reviewed the national interests, the national maritime interests/objectives, and the sources and elements of the RSA's maritime power, an attempt will now be made to identify the elements of a national maritime policy. It has already been determined that a maritime policy will lead to a maritime strategy. Therefore national maritime policy will basically consist of the rules governing the use of the means (maritime power) to meet the national needs (maritime objectives). A study of the RSA's maritime interests and maritime power now allows the completion of a proposed framework for a national maritime policy. The elements identified in the compilation of the framework will be discussed briefly. (Note: Certain of these elements exist already, but a co-ordinated effort is required.) 
32. The Fostering of Sea-mindedness. There is a need to make South Africa generally more seaorientated, to also regard the sea as their means of livelihood.

33. The Allocation of Financial Resources. A policy is required on the allocation of funds to various elements of the RSA's maritime power, e.g shipbuilding subsidies.

34. Sport, Recreation and Tourism. Our beaches and offshore and inshore water areas need to be exploited to the maximum, but with due regard to the ecology, to provide for sport, recreation and tourism.

35. The Management of Manpower. The scarcity of manpower in the seafaring services calls for a manpower management policy to encourage South Africans to go to sea. This policy should address issues like, e.g nautical schools, nautical training in general and the exemption from national service of people in some seafaring careers.

36. Maritime Ecology. The maritime life of the country needs protecting. In this regard all forms of pollution need to be addressed in the national maritime policy.

\section{The Co-ordinated Management of Maritime}

Activities. The establishment of co-ordinated management of maritime activities is the key element of a national maritime policy. There is an urgent need for the creation of a body that will advise Government with respect to national policy. The National Maritime Advisory Council's functions are too limited for this purpose.

38. The Protection of the Fishing Industry. Policy needs to be co-ordinated to confirm the future existence of this industry in the form of physical policing of fishing grounds and preservation of fish life.

39. The Negotiation of Trade Preference Agreements. A policy is needed to govern the negotiation of trade agreements that will include preference clauses to ensure that RSA ships carry a fair percentage of the goods to be freighted to and from our country.

40. Planning and Policy to Overcome Sanctions/ Boycotts. There is a need for planning by SA shipowners to make optimum use of flags of convenience, to provide acceptable passports for RSA crews and overcome the sanctions and boycotts being experienced by our foreigngoing merchant ships.

41. The Protection and Encouragement of the Shipbuilding Industry. The overall economic benefits of local shipbuilding demands a policy that will protect and promote the RSA's shipbuilding industry.

42. The Maritime Research Services. A national maritime policy must ensure that research in the maritime field continues to the advantage of all who make their living in that environment.

43. Survey, Mapping and Aids to Navigation. The policy must indicate the way to rationalise these services, which are vital for those who ply the seas.

44. Rationalisation of Maritime Communications. At present this service is being provided by a number of organisations and the maritime policy is to be the vehicle to rationalise and ensure the best service at sea.

45. Exploitation of Minerals off the Seabed. The maritime policy must ensure that the exploitation takes place in such a way that it is to the advantage of the country as a whole.

46. Rationalisaion of Maritime Defence and Policing Services. These include, apart from our maritime forces, police patrols, coastal watch against pollution and fishery protection. As can be seen, these are once again divided between various government departments and agencies. The national maritime policy must aim at the rationaliation of these services.

47. Conclusion. The fifteen elements proposed to this papaer offered as some of the main elements of a national maritime policy. These elements are interrelated, and are not regarded as changes occur in the components of the RSA's maritime power. The implementation of a national maritime policy would be the task of the coordinating body which was proposed before. This body could be called a Maritime Co-ordinating Authority (MCA). The constitution of such a MCA should be the subject of an investigation by a study-group made up of all involved parties.

\section{Summary}

48. The RSA's national interests have been determined as the fundamental need for economic 
well-being and security. From there, the national maritime interests (the need to use the sea to meet the fundamental needs) have been identified as the exploitation of marine resources, seaborne trade and maritime defence.

49. The sources and elements of the RSA's maritime power (as the means to meet the country's needs) were examined. Geography, national resources, merchant shipping and the maritime infrastructure emerged as strong components, while the maritime community, the style of government and maritime forces were identified as weaker components of the RSA;s maritime power.

50. A framework for a national maritime policy has been draw up, which proposes some fifteen elements for this policy. The elements identified are those that need rules to govern the application of maritime power to meet the country's fundamental needs. One of these fifteen proposed elements was the creation of a Maritime Co-ordinating Authority to formulate a national maritime policy.

\section{Conclusion}

51. The RSA has the potential to become a strong maritime power. The improved well-being of the RSA will be further enhanced by our ability to develop this power and a national maritime policy should be formulated and implemented to bring this about.

* For details of authors, see 1st paragraph, p 40.

\section{Bibliography}

1. DU PLESSIS, A., South Africa and the South Atlantic Ocean: A MaritimeStrategic Analysis. Institute for Strategic Studies, University of Pretoria, June 1987.

2. GORSHKOV, S.G., The Sea Power of the State, Pergamon Press, London, 1979.

3. COLLINS, J.M., Grand Strategy, Practice and Principles, United States Naval Institute Press, Annapolis, 1973.

4. South Africa Year Book - 1987/88. The Official Year Book of the Republic of South Africa, New condensed edition, Thirteenth Edition Perskor Printers, Johannesburg, 1987.

5. Harmonization of North Sea Policy. Netherland Government, 1984.

6. TILL, G., Maritime Strategy and the Nuclear Age, Second Edition, MacMillan Press, London, 1984.

7. MAHAN, A.T., The Influence of Sea Power upon History, Hill and Wang Inc, New York, 1962. 